\title{
The warm compress of clove water (syzygium aromaticum) therapy during bouts of acute gouty arthritis
}

\author{
Rita Sari, Janu Purwono*, Desi Safitri, Pira Prahmawati, Nur Hasanah
}

Fakultas Kesehatan Universitas Muhammadiyah Pringsewu (UMPRI)

*Akper Dharma Wacana Metro. *Corresponding author. E-mail: janupurwono@gmail.com

\begin{abstract}
Background: Non-communicable diseases keep increase numbers in both developed and developing countries such as gout arthritis. Gouty arthritis is an inflammation of the joints caused by high levels of uric acid in the blood (hyperuricemia). Most people with gout arthritis complain of pain in the joints.

Purpose: To determine the effect of cloves water warm compress (syzygium aromaticum) on reducing pain among elderly with gouty arthritis

Method: This study used a quasi-experimental pre and post test without control (self-control) with 11 participants. The data analysis used was the Dependent $T$ test. As for preparing the ingredients, using 5 grams of cloves boiled with $300 \mathrm{cc}$ to boil, let stand for about 1-3 minutes until a warm temperature $\left(45-50^{\circ} \mathrm{C}\right)$, then observe / measure the patient's pain level.

After measuring the pain scale, then apply a compress using a clean cloth on the affected joint for 20 minutes, then measure the pain scale again. This action performs every evening (once) at bedtime repeatedly for 5 consecutive days.

Results: Showed that the intensity of pain before intervention was 6.73 and the average pain intensity after intervention was 3.00. The result of the t-test is 14,907 with a $p$-value of $0,000<a(0.05)$.

Conclusion: The effect had a significantly greater reduction in pain by clove water warm compresses among elderly with gouty arthritis.
\end{abstract}

Keywords: Clove; Water warm; Compress; Therapy; Acute; Gouty arthritis

\section{INTRODUCTION}

In the world of health, there are contagious and non-communicable diseases, non-communicable diseases every day and even every second are increasing both in developed and developing countries, for example, namely gout arthritis (Warganegara, \& Nur, 2016). Gouty arthritis is a painful inflammatory disease in response to monosodium urate crystals (MSU) in joints (Rees, Hui, \& Doherty, 2014; Dalbeth, et al., 2017; Widyanto, 2017) not all hyperuricemia sufferers are sufferers of gout arthritis. but the risk of gout arthritis will further increase blood uric acid levels (Noor, 2016; Zahara, 2013).

The pain experienced by gout patients' arthritis is acute pain. Patients seek medical care because of acute pain and even though they heal on their own (around 10 days), acute gout is one of the most painful experiences for humans (Dalbeth, et al., 2017; Widyanto, 2017; Rees, 2014). According to WHO (World Health Organization) gout arthritis is a disease that has been known since 2000 years ago and is the oldest disease known to humans to date. gout arthritis is an inflammation of the joints caused by high levels of uric acid in the blood (hyperuricemia). If this condition is not immediately treated, infection will occur and the symptoms will worsen (Setiani, \& Karnasih, 2010).

Epidemiological studies show that the incidence and prevalence of uric acid continues to increase, especially in Western countries (Kuo, et al., 2015). Gout results from chronic hyperuricemia and deposition of monosodium urate crystals (MSU) in the joints, which are the cause of acute, recurrent and self-limiting attacks of arthritis. Advances in understanding the pathogenesis of gout and therapeutic developments in recent years, gout is still largely underdiagnosed and not well managed (Dalbeth, et al, 2017; Pascart, \& Liote, 2019; Doherty, et al, 2012; Kuo, et al. , 2015).

According to data obtained based on incidence in the world, for example in the United States, the prevalence of gout in adults increased by 8.3 million people in 2010, while hyperuricemia also 
increased by 43.3 million people compared to the previous year. Meanwhile, in Indonesia, the data for prevalence gout arthritis was 713,783 people (Setiani \& Karnasih, 2010).

Arthritic gout in Lampung ranks seventh with a prevalence of gout arthritis as many as 22,345 people.From the 2018 Riskesdas data shows that the highest area in Lampung with gout arthritis is Lampung Tengah district with 3,434 people, East Lampung ranks second 2,822 and the lowest is in metro city 459 person.

According to the database of Integrated Service Post for Non-Communicable Diseases and interviews of some cadres in the village of gunung Tiga, Batanghari sub-district, Nuban Lampung Timur, the number the elderly sufferers gout was 63 out of 125 elderly. Base on basic health research in the previous year, the incidence of gout arthritis in men was higher than in women, the incident in women will experience an increase after menopause (Ministry of Health of the Republic of Indonesia, 2018).

Based on research conducted by Setiani \& Karnasih, (2010) on the effectiveness in treatment apply clove water warm to reduce uric acid, it found that 8 out of 10 participants experienced a decrease in uric acid levels. clove capsules at a dose of 1, 2, or 3 grams per day You can also take for 14 days significantly reduced uric acid levels in prediabetic women ( $p$ <0.05) (Yunita, \& Murbawani, 2016).

Cloves are annual plants that grow and have a height of 20-30 meters from the ground, have oval leaves, green early fruit and red flowers when they bloom, cloves will be harvested if they reach 1.5-2 $\mathrm{cm}$ in length. Cloves have many benefits, such as: rheumatism, gout arthritis, coughing, colds, toothache, measles and increase heart rate (Wahyuni, et al., 2016).

Eugenol, a methoxy phenol component of clove (Syzygium aromaticum, Family Myrtaceae), has been reported for a number of pharmacological effects, including antioxidant, anti-inflammatory, analgesic, anesthetic, antipyretic, antiplatelet, anti anaphylactic, antidepressant, anti-seizure, antibacterial, antibacterial and antiviral effects. The uses and benefits of eugenol isolated from various sources including Syzygium aromaticum and Ocimum sanctum are numerous (Towaha, 2012). Based on the description above, the aim of the study was to determine the effect of clove water warm compress (syzygium aromaticum) on reducing pain in elderly people with gouty arthritis in Gunung Tiga Village, Batanghari Nuban District, East Lampung Regency.

\section{RESEARCH METHODS}

This study used a quasi-experimental design using a "approach pretest and posttest without control (self-control)". The study conducted from February to May 2020. The population of the elderly was in Gunung Tiga Village, Batanghari Nuban District, East Lampung Regency. The sample consisted of 11

elderly. The data collection method used the interview method which was carried out by interacting, asking and listening to what was conveyed orally by the respondent or participant, filling out the observation sheet. This study used a compress to all participants who experienced joint pain due to gout arthritis. The data analysis of this research used paired sample-t test. The criteria for most participants with gout arthritis suffer from pain for more than one year, have a weight above normal.

The previous therapy was all only using lotion analgesic by rubbing with rubbing oil, such as balm. There were 5 participants who went to the doctor and routinely followed the 4 people doctor's therapy.

As for preparing the ingredients, using 5 grams of cloves boiled with $300 \mathrm{cc}$ to boil, let stand for about 1-3 minutes until a warm temperature (45 $50{ }^{\circ} \mathrm{C}$ ), then observe / measure the patient's pain level; ask the client to state the complaints they feel; adjust the client's position according to the client's comfort level.

After measuring the pain scale, then apply a compress using a clean cloth on the affected joint, for 20 minutes, then measure the pain scale again. This action is performed every evening (once) at bedtime repeatedly for 5 consecutive days.

Rita Sari, Desi Safitri, Pira Prahmawati, Nur Hasanah

Fakultas Kesehatan Universitas Muhammadiyah Pringsewu (UMPRI)

Janu Purwono*, Akper Dharma Wacana Metro. *Corresponding author. E-mail: janupurwono@gmail.com 
Malahayati International Journal of Nursing and Health Science, Volume 03, No.2, September 2020: 117-123

The warm compress of clove water (syzygium aromaticum) therapy during bouts of acute gouty arthritis

RESULT

Table 1. Demographic Characteristics of Participants $\mathrm{N}=11$

\begin{tabular}{|c|c|c|c|c|}
\hline Demographic & & $\mathrm{n}$ & $\%$ & $M \pm S D$ \\
\hline Age (Years) (Range: 51-74) & & & & $60.82 \pm 8.048$ \\
\hline Duration of illness (Years) (Range: 1-15) & & & & $6.82 \pm 4.750$ \\
\hline Gender & $\begin{array}{l}\text { Male } \\
\text { Female }\end{array}$ & $\begin{array}{l}2 \\
9\end{array}$ & $\begin{array}{l}18.2 \\
81.8\end{array}$ & \\
\hline Educational level & $\begin{array}{l}\text { Elementary School } \\
\text { Junior High School }\end{array}$ & $\begin{array}{l}9 \\
2\end{array}$ & $\begin{array}{l}81.8 \\
18.2\end{array}$ & \\
\hline Occupation & $\begin{array}{l}\text { Employed } \\
\text { Not employed and retired }\end{array}$ & $\begin{array}{l}3 \\
8\end{array}$ & $\begin{array}{l}27.3 \\
72.7\end{array}$ & \\
\hline Body Weight & $\begin{array}{l}\text { Ideal } \\
\text { Obesity }\end{array}$ & $\begin{array}{l}3 \\
8\end{array}$ & $\begin{array}{l}27.3 \\
72.7\end{array}$ & \\
\hline Has a regular medical care & $\begin{array}{l}\text { Has } \\
\text { Has not }\end{array}$ & $\begin{array}{l}5 \\
6\end{array}$ & $\begin{array}{l}45.5 \\
54.5\end{array}$ & \\
\hline Compliance with medication & $\begin{array}{l}\text { Routine/regular } \\
\text { Not routine }\end{array}$ & $\begin{array}{l}4 \\
7\end{array}$ & $\begin{array}{l}36.4 \\
63.6\end{array}$ & \\
\hline
\end{tabular}

Based on table 1. it is known that 11 participants were aged between 51 years up to 74 years with a mean of 60.82 and a standard deviation of 8,048 . Participants were male as many as 2 people $(18.2 \%)$ and female as many as 9 people (81.8\%). Most of the participants' education is elementary school $(81.8 \%)$, and is dominated by participants who has not employed and retired $(72.7 \%)$.

Table 2. Average Pain Before and After Intervention for Gouty Arthritis Pain N = 11

\begin{tabular}{llllll}
\hline Pain & N & Mean & Min & Max & SD \\
& & & & & \\
\hline - Before & 11 & 6.73 & 6 & 9 & 1.009 \\
- After & 11 & 3.09 & 2 & 6 & 1.221 \\
\hline
\end{tabular}

Based on table 2., it is known that the average patient before intervention (syzygium aromaticum) was 6.73, the lowest value was 6 and the highest was 9 with a standard deviation of 1.009 . While the average patient after intervention decreased, of 3.09 with a minimum value of 8 and a maximum of 24 .

Rita Sari, Desi Safitri, Pira Prahmawati, Nur Hasanah

Fakultas Kesehatan Universitas Muhammadiyah Pringsewu (UMPRI)

Janu Purwono*, Akper Dharma Wacana Metro. *Corresponding author. E-mail: janupurwono@gmail.com 
Malahayati International Journal of Nursing and Health Science, Volume 03, No.2, September 2020: 117-123

The warm compress of clove water (syzygium aromaticum) therapy during bouts of acute gouty arthritis

Table 3. Effect of Clove Water Warm Compress (Syzygium Aromaticum) N = 11

\begin{tabular}{lllllll}
\hline Pain & \multicolumn{2}{l}{ Intervensi } & & \multicolumn{3}{c}{ T test } \\
\cline { 2 - 7 } & $\mathbf{N}$ & Mean & SD & T & Df & $p$ value \\
\hline Before Intervention & 11 & 6.73 & 1.009 & 14.907 & 10 & 0.000 \\
After Intervention & 11 & 3.00 & 1.221 & 14.907 & 10 & \\
\hline
\end{tabular}

Based on table 3 above, it was found that the average pain intensity before intervention was 6.73 and the average pain intensity after intervention of 3.00. The result of the t-test is 14,907 with a $p$ value of $0,000<a(0.05)$.

\section{DISCUSSION}

Arthritic gout is the most common inflammatory joint disease in men aged $>40$ years (overall age standard prevalence is $0.08 \%$, or $0.13 \%$ in men and $0.03 \%$ in women. Gouty arthritis is a joint disease caused by sedimentation. monosodium urate, is associated with disorders of purine metabolism (Widyanto, 2017; Smith, et al., 2014). Although pain may be the first complaint of patients with gout, effective treatment must take into account pain and potential inflammation (Wechalekar, et al., 2014).

Arthritic gout lasts for almost 10 days with intense and debilitating pain despite antiinflammatory treatment (Martin, \& Harper, 2010). However, if left untreated, the continuous deposition of MSU crystals causes recurrent complaints. irreversible chronic symptoms and disability can be observed.In fact, advanced cases of gout are characterized by chronic joint pain, limited movement, and recurrent flares. (Rees, et al., 2014; Dalbeth, et al., 2017).

The results of statistical test analysis in this study indicate that there is an effect of clove water warm compress (syzygium aromaticum) on the reduction of pain intensity in elderly people with gout arthritis in Gunung Tiga village, the average pain intensity before being compress of 6.73 and after compress of 3.00 , the results of the t-test is 14.907 with a $p$ value of $0.000<a(0.05)$.

Medically, currently the treatment of gout arthritis usesanti-inflammatory non-steroidal drugs (NSAIDs) and these drugs are not only used for analgesia, but also to inhibit inflammation (Khanna, et al., 2012). Other researchers said prednisolone, etorikoxib, and indomethacin in treating gouty arthritis were more effective in reducing inflammation and were better tolerated (Xu, Liu, Guan, \& Xue, 2016).

However, the non-pharmacological treatment carried out by Setiani, \& Karnasi. (2010) stated that the provision of clove water was effective in reducing uric acid / gout arthritis in the elderly at the posyandu for elderly RW 06 Blunyah rejoTegal rejo, Yogyakarta, in addition to Yunita, \& Murbawani, 2016) also stated that there was a significant difference between the pain before and after being given gotu kola compresses with an average difference of 1.42, while the average difference before and after being given clove compresses was 3.29 in the Work Area. Secang II Public Health Center.

The results of the study are also in line with those conducted by Mustapa, et al., 2019) which showed the results of the study were $p$ value $<0.05$, which means that there is an effect of giving clove capsules on uric acid in prediabetic women. Other studies have also shown that the combination of the herbal medicine pinogu coffee (Coffea canephora var robusta) and clove flowers (Syzygium aromaticum) can reduce uric acid levels in male white mice (mus musculus).

Pain due to gout arthritis can be reduced by giving warm compress therapy with clove water because cloves contain essential oils that can relieve joint pain, one of which is for the treatment of gout arthritis and helps treat stomach ulcers, inhibits bacterial growth, prevents premature ejaculation, maintains liver health, and maintains health. bones (Setiani, \& Karnasih, 2010).

Cloves contain active substances, including essential oils. Cloves also contain other nutrients

Rita Sari, Desi Safitri, Pira Prahmawati, Nur Hasanah

Fakultas Kesehatan Universitas Muhammadiyah Pringsewu (UMPRI)

Janu Purwono*, Akper Dharma Wacana Metro. ${ }^{*}$ Corresponding author. E-mail: janupurwono@gmail.com 
potassium, manganese, calcium, magnesium sodium, zinc, folate, antioxidants, vitamin $\mathrm{A}$, vitamin $C$, vitamin $E$, and vitamin $K$. So it's not surprising that these various nutrients support the benefits of cloves for body health (Rahmawati,

2020). The components of cloves are eugenol, eugenol and their derivatives in cloves are strong antioxidants (Fariasa, et al., 2013). The essential oil extracted from cloves is used as a topical application to relieve pain and promote healing (Yana, Malik, \& Kurniawan, 2018).

The clove water warm compress used for gout arthritis because they can reduce joint pain, reduce compression or compression of joint pain, so that after compressing with cloves water can relax stiff muscles and can flex connective tissue. So that by intervention, it can inhibit the pain receptor mechanism in large nerve fibers which will result in a change in mechanism, namely the gate that will modify and change the sensation of pain causing pain perception and muscle receptors so that pain can be reduced.

Based on the descriptions above, the researchers concluded that the intervention of clove water warm compressed the part that experienced joint pain experienced a decrease in pain intensity because cloves are a traditional treatment without chemicals and are able to treat pain in the elderly suffering from arthritis gout. Compress with clove water can open blood vessels so that it can accelerate blood circulation and better supply of food and oxygen so that joint pain can be reduced.

\section{CONCLUSION}

There is an effect of clove water warm compress (Syzygium Aromaticum) on reducing pain intensity in elderly with gouty arthritis.

\section{SUGGESTION}

For elderly people with arthritis gout to use traditional clove medicine to treat pain because cloves are easy to obtain, without side effects, effective, and cheap. Researchers hope that research can be developed on the use of nonpharmacological therapies in the elderly with arthritis gout.

\section{REFERENCES}

Dalbeth, N., Stamp, L. K., \& Merriman, T. R. (2017). The genetics of gout: towards personalised medicine?. BMC medicine, 15(1), $1-8$.

Doherty, M., Jansen, T. L., Nuki, G., Pascual, E., Perez-Ruiz, F., Punzi, L., \& Bardin, T. (2012). Gout: why is this curable disease so seldom cured?. Annals of the rheumatic diseases, 71(11), 1765-1770.

Fariasa, M. D. A., Oliveiraa, P. S., Dutrac, F. S. P., Fernandesc, T. J., de Pereiraa, C. M., de Oliveirad, S. Q., \& Barschaka, A. G. (2013). Eugenol derivatives as potential anti-oxidants: is phenolic hydroxyl necessary to obtain an effect?

Khanna, D., Fitzgerald, J. D., Khanna, P. P., Bae, S., Singh, M. K., Neogi, T., \& Kaldas, M. (2012). 2012 American College of Rheumatology guidelines for management of gout. Part 1: systematic nonpharmacologic and pharmacologic therapeutic approaches to hyperuricemia. Arthritis care \& research, 64(10), 1431-1446.

Kuo, C. F., Grainge, M. J., Mallen, C., Zhang, W., \& Doherty, M. (2015). Rising burden of gout in the UK but continuing suboptimal management: a nationwide population study. Annals of the rheumatic diseases, 74(4), 661-667.

Kuo, C. F., Grainge, M. J., Zhang, W., \& Doherty, M. (2015). Global epidemiology of gout: prevalence, incidence and risk factors. Nature reviews rheumatology, 11(11), 649.

Rita Sari, Desi Safitri, Pira Prahmawati, Nur Hasanah

Fakultas Kesehatan Universitas Muhammadiyah Pringsewu (UMPRI)

Janu Purwono*, Akper Dharma Wacana Metro. *Corresponding author. E-mail: janupurwono@gmail.com 
Malahayati International Journal of Nursing and Health Science, Volume 03, No.2, September 2020: 117-123

The warm compress of clove water (syzygium aromaticum) therapy during bouts of acute gouty arthritis

Martin, W. J., \& Harper, J. L. (2010). Innate inflammation and resolution in acute gout. Immunology and Cell Biology, 88(1), 1519.

Ministry of Health of the Republic of Indonesia. (2018). Main results of basic health research 2018. Retrieved from: https://www.kemkes.go.id/resources/download/i nfo-terkini/hasil-riskesdas-2018.pdf

Mustapa, M. A., Taupik, M., \& Hanapi, F. (2019). Uji Praklinik Kombinasi Obat Herbal Kopi Pinogu (Coffea canephora var Robusta) Dan Bunga Cengkeh (Syzygium aromaticum) Terhadap Penurunan Kadar Asam Urat Pada Mencit. Parapemikir: Jurnal IImiah Farmasi, 8(2), 14-20.

Noor, Z. (2016). Buku Ajar Gangguan Muskuloskeletal. II). Jakarta: Salemba Medika.

Pascart, T., \& Lioté, F. (2019). Gout: state of the art after a decade of developments. Rheumatology, 58(1), 27-44.

Rahmawati, V. (2020). Manajemen Persediaan Bahan Baku Minyak Atsiri Pada Industri Penyulingan Minyak Cengkeh Di Desa Balukang Kecamatan Sojol Kabupaten Donggala (Doctoral dissertation, Universitas Tadulako).

Rees, F., Hui, M., \& Doherty, M. (2014). Optimizing current treatment of gout. Nature Reviews Rheumatology, 10(5), 271.

Setiani, D., \& Karnasih, W. (2010). Efektivitas Pemberian Air Rebusan Cengkeh terhadap Penurunan Asam Urat pada Usia Lanjut di Posyandu Lansia RW 06, Blunyahrejo,
Tegalrejo, Yogyakarta (Doctoral dissertation, STIKES'Aisyiyah Yogyakarta).

Setiani, D., \& Karnasih, W. (2010). Efektivitas Pemberian Air Rebusan Cengkeh terhadap Penurunan Asam Urat pada Usia Lanjut di Posyandu Lansia RW 06, Blunyahrejo, Tegalrejo, Yogyakarta (Doctoral dissertation, STIKES'Aisyiyah Yogyakarta).

Smith, E., Hoy, D., Cross, M., Merriman, T. R., Vos, T., Buchbinder, R., \& March, L. (2014). The global burden of gout: estimates from the Global Burden of Disease 2010 study. Annals of the rheumatic diseases, 73(8), 1470-1476.

Towaha, J. (2012). Manfaat eugenol cengkeh dalam berbagai industri di Indonesia. Perspektif, 11(2), 79-90.

Wahyuni, D. K., Ekasari, W., Witono, J. R., \& Purnobasuki, H. (2016). Toga Indonesia. Surabaya: Airlangga University Press.

Warganegara, E., \& Nur, N. N. (2016). Faktor risiko perilaku penyakit tidak menular. Jurnal Majority, 5(2), 88-94.

Wechalekar, M. D., Vinik, O., Moi, J. H., Sivera, F., van Echteld, I. A., van Durme, C., \& Landewé, R. B. (2014). The efficacy and safety of treatments for acute gout: results from a series of systematic literature reviews including Cochrane reviews on intraarticular glucocorticoids, colchicine, nonsteroidal antiinflammatory drugs, and interleukin-1 inhibitors. The Journal of Rheumatology Supplement, 92, 15-25.

Rita Sari, Desi Safitri, Pira Prahmawati, Nur Hasanah

Fakultas Kesehatan Universitas Muhammadiyah Pringsewu (UMPRI)

Janu Purwono*, Akper Dharma Wacana Metro. *Corresponding author. E-mail: janupurwono@gmail.com 
The warm compress of clove water (syzygium aromaticum) therapy during bouts of acute gouty arthritis

Widyanto, F. W. (2017). Artritis gout dan perkembangannya. Saintika Medika: Jurnal IImu Kesehatan dan Kedokteran Keluarga, 10(2), 145-152.

Xu, L., Liu, S., Guan, M., \& Xue, Y. (2016). Comparison of prednisolone, etoricoxib, and indomethacin in treatment of acute gouty arthritis: an open-label, randomized, controlled trial. Medical science monitor: international medical journal of experimental and clinical research, 22, 810.

Yana, T., Malik, A., \& Kurniawan, F. (2018). Study jenis rempah-rempah dan pemanfaatannya di pasar tradisional angso duo (Doctoral dissertation, UIN Sulthan Thaha Saifuddin Jambi).
Yunita, R. D., \& Murbawani, E. A. (2016). Pengaruh Pemberian Kapsul Cengkih Terhadap Kadar Asam Urat Pada Wanita Prediabetes (Doctoral dissertation, Diponegoro University).

Zahara, R. (2013). Artritis Gout Metakarpal dengan Perilaku Makan Tinggi Purin Diperberat oleh Aktifitas Mekanik Pada Kepala Keluarga dengan Posisi Menggenggam Statis. Jurnal Medula, 1(03), 67-76.

Rita Sari, Desi Safitri, Pira Prahmawati, Nur Hasanah 